\title{
Amniotic band syndrome: a new case report
}

\author{
Aissatou Mbodji ${ }^{1 *}$, Mouhamadou Wade ${ }^{1}$, Mamour Gueye ${ }^{1}$, Mame D. Ndiaye ${ }^{1}$, \\ Aliou D. Dia ${ }^{1}$, Mouhamed Sene ${ }^{1}$, Pahté Sow ${ }^{1}$, \\ Aminata T. Gueye ${ }^{1}$, Magatte Mbaye ${ }^{2}$
}

\begin{abstract}
${ }^{1}$ Ancien interne des hôpitaux Gynécologue Obstétricienne, Université Cheikh Anta DIOP, Dakar, Sénégal
${ }^{2}$ Université Gaston Berger, Saint Louis, Sénégal
\end{abstract}

Received: 05 May 2021

Accepted: 31 May 2021

\section{*Correspondence:}

Dr. Aissatou Mbodji,

E-mail: aissa2908@live.fr

Copyright: (c) the author(s), publisher and licensee Medip Academy. This is an open-access article distributed under the terms of the Creative Commons Attribution Non-Commercial License, which permits unrestricted non-commercial use, distribution, and reproduction in any medium, provided the original work is properly cited.

\begin{abstract}
Amniotic band syndrome is a pathology affecting the extremities of the fetus. It is uncommon with rates around 1 per 10,000 births. The pathophysiology is poorly understood until now with several theories reported in the literature. The diagnosis is most often made at birth. We reported a case of a 40 year old patient with no particular history who had consulted for spontaneous premature rupture of membranes in a 20 weeks pregnancy. The diagnostic of amniotic band syndrome was made after the delivery with amputation of a limb, amniotic syndactilia and deformation of the right foot in equinovarus.
\end{abstract}

Keywords: Amniotic band syndrome, Malformation, Amputation

\section{INTRODUCTION}

Amniotic band syndrome is characterised by various congenital defects due to constriction of one or more parts of the foetus by fibrous bands derived from the amniotic sac. ${ }^{1}$ It is a complex disorder characterized by several abnormalities including constriction band syndrome, adhesions, mutilations and amniotic deformities. ${ }^{2,3}$ The frequency is estimated to be around one case per 10,00015,000 births., ${ }^{2,4}$ This condition is included in the Swanson classification of limb defects, specifically in group VI. ${ }^{5}$

It is commonly accepted that it is a disorder of disruptive and non-malformative origin. ${ }^{6}$ However, the pathophysiology of this pathology is still poorly understood. Several theories have been reported since the first description: inflammatory reactions (Chiari, 1911), abnormal development of the amnion (Lennon, 1947), defective development of fetal tissues (Streeter, 1930) and rupture of the premature amnion (Torpin, 1965). ${ }^{7}$

The diagnosis is most often made after delivery when abnormalities of the foetal extremities are discovered, varying from stricture to amputation with lesions that are not symmetrical.

The prognosis is functional depending on the degree of mutilation. Rare severe cases with brain damage have been reported in the literature. ${ }^{3}$

We reported the case of a newborn in whom the diagnosis of amniotic band syndrome was made at birth, which allowed us to review the literature on the pathophysiological and diagnostic aspects of this pathology. 


\section{CASE REPORT}

Mrs. A. M., 40 years old with no particular history had consulted for spontaneous premature rupture of membranes in pregnancy of 20 weeks.

The obstetrical examination revealed an absence of uterine contractions with no cervical modification. An ultrasound scan carried out in the department showed an evolving intrauterine monofetal pregnancy with severe oligohydramnios. She was admitted to the department with parenteral antibiotic therapy. The follow-up of the pregnancy was unremarkable with appointments every 15 days with regular biological tests to check the white blood cell count and the C-reactive protein level. Several ultrasound scans performed afterwards came back without any particularities apart from the amnanios which made complete morphological exploration difficult. The patient went into labour spontaneously at 30 weeks gestation with vaginal delivery of a male infant weighing $1440 \mathrm{~g}$ with an Apgar score of 7 at five minutes.

The birth examination revealed several abnormalities of the fetal extremities such as a section of the right foot at the ankle (Figure 1B). There was also syndactyly of the index and middle fingers of the right hand and in the left hand there was partial sectioning of the fingers with syndactyly of the stumps (Figure $1 \mathrm{~A}$ and D). On the back of the left knee there was an ulcerated area in favour of constriction with clubfoot deformity in equinovarus (Figure 1C). The newborn was transferred to a paediatric surgical unit.

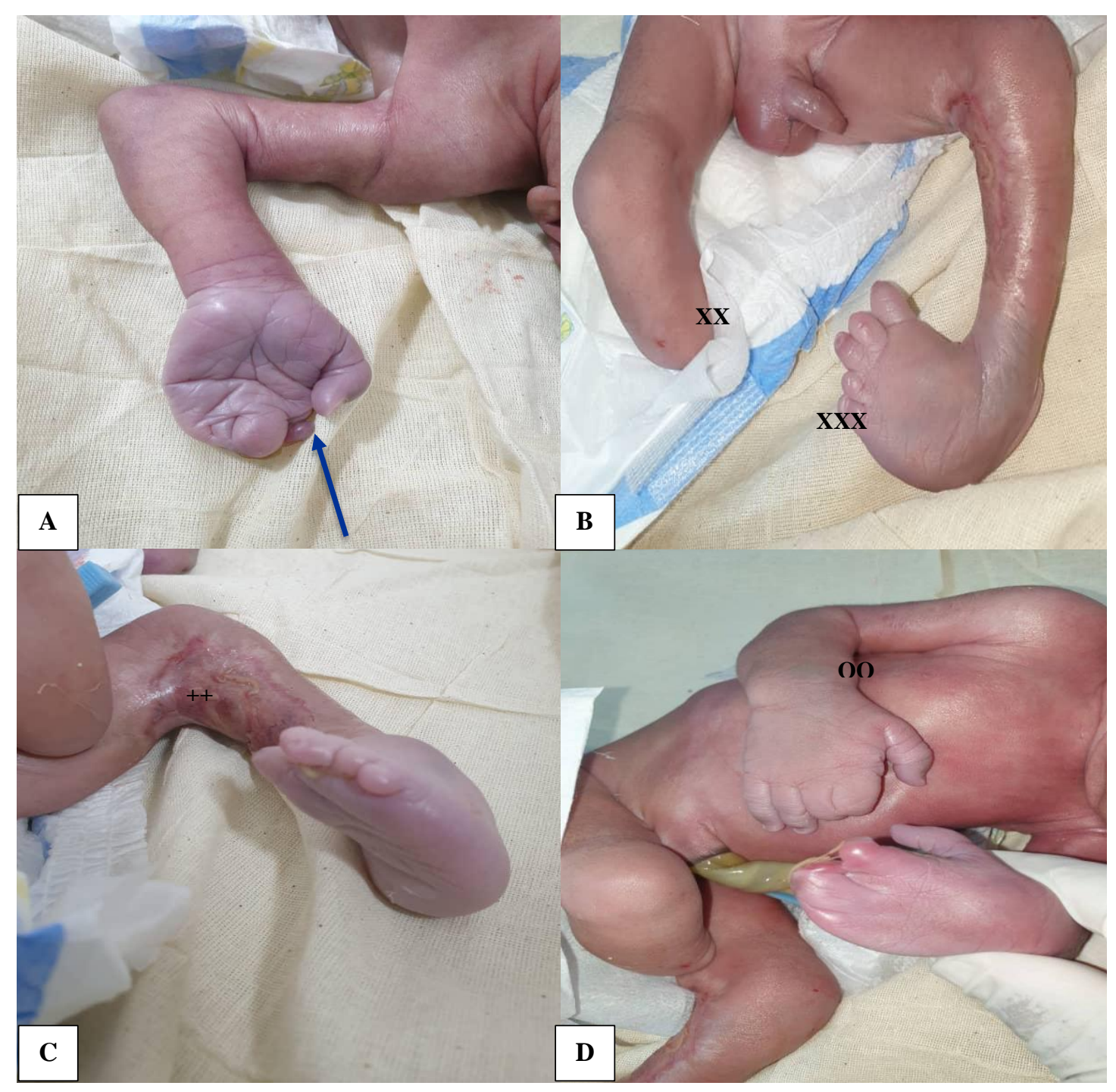

Figure 1: Fetal lesions observed at birth in amniotic band syndrome; (A) amniotic syndactilia of the fingers (blue arrow); (B) amputation of the right leg (XX) and deformation of the left leg in equinovarus (XXX); (C) ulcerated area in favour of constriction (++); (D) amniotic syndactilia of the fingers (OO). 


\section{DISCUSSION}

Amniotic band syndrome is a complex condition that may involve several fetal abnormalities. It is characterized clinically by the association of pathognomonic signs like presence of bands, cutaneous strictures, amputations of the extremities and pseudo syndactylies. Rarely we can find atypical facial clefts and exencephaly. It is a disease which is the subject of many names in the Anglo-Saxon literature: aberrant tissue bands, ADAM complex (amniotic, deformity, adhesion, mutilation), amniochorionic mesoblastic fibrous strings, amniogenic bands, amniotic bands disruption complex, congenital constriction band syndrome, congenital ring constrictions. ${ }^{8}$

It is a rare condition, the frequency is estimated to be around one case per 10,000-15,000 births. ${ }^{2,4}$ But underestimated, especially in our African countries where there are not many cases reported in the literature.

The pathogenesis has been described for a long time and is still not well understood, although several theories have been put forward. The two most frequently reported are those of Streeter in the 1930 intrinsic model, based on the study of 16 fetuses and suggests that there is an early anomaly in the development of the embryonic disc before the 3rd week of gestation. Later, Torpin's model of the 1965, the extrinsic theory, suggested that the birth defects are caused by the action of the fibrous amniotic bands secondary to the rupture of the amnion, followed by loss of amniotic fluid and extrusion of all or parts of the fetus into the chorionic cavity. ${ }^{2,3,8,9}$ This second theory is the most frequently reported with several cases of ABS occurring in the context of an extra amniotic pregnancy as was the case for our patient.

The diagnosis is made at birth in the presence of one of the typical limb anomalies: amniotic grooves, acrosyndactyly, intrauterine amputations. The diagnosis, even if it is most often made in the postpartum period, is possible in the antenatal period with rigorous ultrasound exploration, especially in the context of rupture of the membranes described above, allowing the presence of amniotic bands, limb sections and deformities of the extremities to be suspected. ${ }^{3,9,10}$ This antenatal diagnosis can be difficult in this context with oligohydramnios or even anamnios making ultrasound exploration difficult. However, this antenatal diagnosis would be important in order to propose antenatal management or to terminate the pregnancy if the fetus is viable in order to avoid aggravation or the appearance of other lesions.

Especially in cases of premature rupture of the membranes occurring very early in the pregnancy as was the case for our patient, it is important to evaluate the advantage to achieve the pregnancy depending primarily on the term and the presence or not of maternal and fetal complications.

At birth, the management is multidisciplinary between surgeon-paediatrician and orthopaedic surgeon allowing a recovery of the functional prognosis of the affected limbs.

\section{CONCLUSION}

Amniotic band syndrome is a rare pathology affecting the fetus during pregnancy. The physiopathology is poorly elucidated even if several authors incriminate the premature rupture of the membranes occurring very early during the pregnancy as it was the case of our patient. The prognosis is essentially functional.

\section{Funding: No funding sources Conflict of interest: None declared \\ Ethical approval: Not required}

\section{REFERENCES}

1. Masmoudi K, Mtaoumi M, Bouattour K, Ayeche MLB. Neonatal leg fracture and constriction ring syndrome: a case report and literature review. Orthop Traumatol Surg Res. 2016;102(7):955-8.

2. Idris UA. Amniotic band syndrome. Arch Med Health Sci. 2018;6(2):260-1.

3. Padmanabhan LD, Hamza ZV, Thampi MV, Nampoothiri S. Prenatal diagnosis of amniotic band syndrome. Indian J Radiol Imaging. 2016;26(1):63-6.

4. Ameziane L, El Bardouni A, El Manouar M. La maladie amniotique à propos d'un cas. Médecine du Maghreb. 1999;77:33-4.

5. Poeuf B, Samson P, Magalon G. Syndrome des brides amniotiques. Chirurgie De Main. 2008;27:136-47.

6. Oberg KC. Classification of congenital upper limb anomalies: towards improved communication, diagnosis and discovery. JHS. 2019;44(1):4-14.

7. Rehder H. Fetal limb deformities due to amniotic constrictions (a possible consequence of preceding amniocentesis). Path Res Pract. 1978;162(3):316-26.

8. Hilali A. La maladie des brides amniotiques aspects orthopédiques et thérapeutiques : à propos d'une série de 24 cas. Université Mohammed. 2013.

9. Nagalo K, Badiel R, Kouéta F, Tall FH, Yé D. Le syndrome des brides amniotiques et ses difficultés diagnostiques et de prise en charge au Burkina Faso. Pan African Medical Journal. 2015;20:208.

10. Adadi H, Chaara H, Attar I, Jayi S, Alaoui FZF, Melhouf MA. Maladie des brides amniotiques: diagnostic anténatal et difficultés de prise en charge (à propos de 02 cas de malformations létales). Pan African Medical Journal. 2019;32:116.

Cite this article as: Mbodji A, Wade M, Gueye M, Ndiaye MD, Dia AD, Sene M, et al. Amniotic band syndrome: a new case report. Int J Reprod Contracept Obstet Gynecol 2021;10:2864-6. 